\title{
Наследството
}

Това е пиеса за любовта. Любовта, която чака и тьрси път, за да се осъществи. В България, в един провинциален град, едно момиче се събужда след автомобилна катастрофа. След години спомените и съновиденията се превръщат в част от нейния живот. Тя ще тръгне след тях, за да разкрие семейни тайни, как алчността погубва човешки животи и преобръща съдби. Защо семейството на Ани получава като наследство къщата? Дали една катастрофа е справедливост, или вик за помощ? Кой е в последния сън на Ани? Отговорите в пиесата „Наследството“.

\section{ДЕЙСТВАЩИ ЛИЦА}

\author{
АНИ \\ ВАСИЛ брат на бащата на Ани \\ ГЕРГАНА сестра на бащата на Ани \\ бялата рокля, убит от своя братовчед \\ БИБЛИОТЕКАРКА Жена на около 60 години \\ БАБА с бяла роКля \\ РАЗКАЗВАЧ гласът на бабата с бяла рокля

\section{ПЪРВО ДЕЙСТВИЕ}

\section{нощ}

ПЪРВО СЪНОВИДЕНИЕ мъЖ На около 40 2., дядото на Ани

ВТОРО СЪНОВИДЕНИЕ мъж на около 30 г., братовчед на бабата на Ани

ТРЕТО СЪНОВИДЕНИЕ мъж на 20 години, брат на бабата на Ани, годеник на жената $c$

Действието се развива в провинциален град в дома на семейство Неделчеви. Времето на действието се определя чрез календар на стената: Ани е на двадесет години, десет години след първата катастрофа.

РАЗКАЗВАЧ - гласът на бабата с бяла рокля: Необикновени са пътуванията на хората. Всеки ден някой тръгва за някъде: за работа, за среща с приятели, някой пътува за вкъщи. Има много начини хората да пътуват. Случва се някое от тях да започне с автомобил и хората пътуват с усещането, че ще се случи нещо хубаво в следващия момент. Но уви, не винаги е така. Понякога пътуването отвежда до най-неочаквани места. Възможно е да започне с автомобил и да завърши в сънищата, където всеки сам търси отговорите на въпроса за къде пътува.

В стаята има гардероб, огледало, спалня. Има масичка с лист и химикал на нея. 
Таня Йорданова (Таня Рейн) е изследовател на темата за парите в родовата динамика. Разрушава стереотипите, за да проучи влиянието на решенията, които се вземат в дългосрочен аспект. В момента е докторантка в $С А$ „Д. Ценов“, гр. Свищов.

\section{ПЪРВА СЦЕНА}

Тъмно е. Звук от силен удар - катастрофа. После се чува как дъждовни капки се стичат по стъклата. Миг тишина. Чуват се викове, бълнувания, стонове. Влизат трите съновидения, отразени в огледалото. Постепенно се вижда, че на спалнята спи някой, а сънят се разказва от съновиденията.

Докато тече сцената, продължава да се чува звук от сирена на линейка. Някакви хора говорят. Някой плаче.

\section{ПЪРВО СЪНОВИДЕНИЕ}

Сънуваш катастрофата, Ани. Опитваш се да си спомниш какво ти говорех в оня момент на безсъзнание. Моментът между живота и смъртта. Измъчват те кошмари. Време е да се събудиш вече. Баба ти, моята жена, загина при катастрофата. Какво още трябваше да се случи, за да се събудят моите деца? Но не. Те не разбраха как да живеят. Продължиха да се мамят. Щом те не могат, тогава ти се събуди, Ани. Нали си ми внучка, нали носиш моята кръв. О, как обичах баба ти.

Той посегна на честта й. Това беше нашата тайна с нея. Това беше нашата семейна тайна. Това беше тайна, която всички знаеха. Хората постепенно започнаха да ме избягват. Нямаше с кого да говоря. В мен остана тайната. Накрая се разболях от рак и си отидох десет години по-късно. Всички въздъхнаха, като помислиха, че с това си отива тайната. Не, една тайна никога не си отива със смъртта на хората. Една тайна си отива, когато се разкаже. А когато се премълчава, тя напомня за себе си чрез болести, катастрофи, неочаквани събития. Остане ли тайна, продължава да живее. Хората не разбират, че случващото се е част от тайната. Постепенно времето заличава следите и само несбъднатите мечти и разочарования на хората могат да измерят колко страшна е била тайната. Събуди се, мила внучке. Ти се върна, за да разкажеш тайната на семейството.

Отива до прозореца. Гледа дъжда. После до масата. На нея има снимка на Ани и баба ѝ. Взема снимката, разглежда я.

\section{ВТОРО СЪНОВИДЕНИЕ}

Сънуваш катастрофата, Ани. Питаш се защо те измъчват кошмари. Питаш се кой съм. Никога не си чувала за мен. Аз съм този, който опетни честта на баба ти. Алчността и завистта ме погубиха.

Исках с измама да взема богатството на семейството на баба ти. Престорих се на влюбен, опетних честта ѝ. Бях измамник. Пропилях богатството, което ми оставиха моите родители. Те си отидоха, докато аз бях почти дете. Лесно тръгнах след лошите съвети на приятели. Когато пропилях всичко, се оказах сам. Лошото беше, че дължах пари. 
Заплашваха ме. Как можех да се измъкна. Само ако се оженя за богато момиче и взема зестрата иे. Баба ти беше и красива, и моя братовчедка. Започнах често да ходя у тях. В началото никой не се учуди, нали сме роднини. Така продължих известно време и хората започнаха да говорят, че има нещо между нас. Тя беше толкова срамежлива, че не смееше да каже, че не е вярно. Един ден, когато пак бях у тях, тя изведнъж се развика и каза да спра с лъжите, защото обича друг човек и че са си дали дума да се оженят по Коледа. Изтръпнах. Всичко се проваляше.

Тогава замислих друга измама. Започнах да разпространявам слухове, че брат й е против нашата любов. Той знаеше, че дължа пари на много хора. Организирах убийството му, като го подмамих една вечер с историята, че ще бягаме със сестра му, за да се оженим в града. Мислех, че като падне петно върху честта й, като премахна брат й и тя ще се ожени за мен. Но както се казва, човек предполага, а Бог разполага. Убих братовчед си и избягах. Ани се поболя от мъка. Родителите й се споминаха. А тя дари всичкото наследено богатство на един манастир и отиде да живее при някаква своя леля в друг град. Дядо ти не я забрави обаче. След една година се ожениха.

Минаха години, озлобих се. Още по-зле стана положението ми. Върнах се, вече никой не ме помнеше. Живеех в края на града в една барака. Каквото изкарвах през деня от работа, вечер го изпивах. Баба ти и дядо ти вече имаха четири деца. Дядо ти беше работлив човек. Живееха щастливо. Понякога отивах на края на улицата, на която живееха, и слушах смеха и песните, които идваха от дома им. Питах се защо се получи така. Мислех си, че ако тя беше избрала мен, щяхме да бъдем щастливи.

Един ден потропах на вратата им. Знаех, че няма никой, дядо ти беше заминал по работа. Децата бяха на училище. Тя ме позна. Поисках някаква работа да свърша, но тя каза да дойда друг път, когато дядо ти е у дома. Поисках хляб. Тя отиде да вземе. И аз влязох след нея. Не се сдържах. Толкова ме беше яд на нея. Изнасилих я. Последното, което помня от нея, е как гледаше в една точка, свлечена на земята.

Убих човек, посегнах на честта на братовчедка си. Никой не говори за мен. Никой не споменава името ми. Стоя на предела между живота и смъртта и не мога да премина отвъд. Разкажи за мен, Ани. За моите грехове. Душата ми ще намери покой само така.

Отдръпва се в ъгъла и стои с поглед към прозореца.

\section{ТРЕТО СЪНОВИДЕНИЕ}

Сънуваш катастрофата, Ани. Влизам в сънищата ти. Аз съм братът на баба ти. Убиха ме заради измама. Как лесно повярвах на лъжите на един човек, който е мой братовчед, а за мен беше повече от брат. Защо не попитах сестра си дали е истина това, което се говореше, че са влюбени и ще бягат. Само един човек остана, който ме помни. Любовта на живота ми. Ние щяхме да се женим. Остана й само бялата рокля. Единственото, което искам, е да прегърна моята любима. Колко много се измори душата ми.

Отдръпва се до прозореца. Стои с наведена глава. Раменете му са отпуснати и се тресат от глух плач.

\section{ПЪРВО СЪНОВИДЕНИЕ}

Ани, чуваш ли? Върнахме се, за да разкажеш за нас. Събуди се. Не оставяй душите ни да скитат още.

Връщат се в огледалото, в реда в който са излезли от него. 